\title{
THE STRUCTURE AND FINANCIAL ACTIVITIES OF THE EUROPEAN REGIONAL COMMUNITIES*
}

\author{
Giandomenico Sertoli $\dagger$
}

The three Communities-European Coal and Steel Community (E.C.S.C.), European Atomic Energy Community (Euratom), and the European Economic Community (E.E.C.)-have, without doubt, a common origin: namely, the will of the six member countries to establish the foundations of an ever closer union between the European peoples. In addition, they exhibit, at least at first sight, the same institutional structure. Each of the Communities is composed of an Executive (the High Authority in E.C.S.C., the Commission in Euratom and E.E.C.), a Council of Ministers, a Parliamentary Assembly, and a Court of Justice. The last three institutions, moreover, are unique and common to the three Communities. Finally, in the sphere of administration of the Executives, certain common staffs have been established.

Although the analogies and common interests between the Communities are numerous and important and although one can foresee, and at the same time hope for, ultimate progress in the direction of unification, it must be admitted that, in the present state of affairs, the three Communities differ appreciably among themselves so far as their structure and their means of action are concerned. These differences are due primarily to the diversity of the objectives which they seek to attain. Two of them, E.C.S.C. and Euratom, are, in fact, specialized Communities with limited powers over a determined sector of production. The third, E.E.C., has, on the contrary, wider tasks-its final object being to fuse the economic systems of the member countries into a single economic entity spreading over all sectors of production and trade. Also these differences are due to the diversity of the political situations existing in the member countries at the time when the treaties setting up these Communities were negotiated and signed, this diversity being reflected alike in their structure and in the means placed at their disposal.

I

\section{The European Coal and Steel Community}

\section{A. Its Tasks}

The E.C.S.C. was instituted by the Treaty of April 18 , r95i, and saw the light of day a few years after the end of the war, when the European economic system was experiencing a marked slow-down in very large sectors. In spite of the efforts

- The author's treatment and analysis of the subject of this article is dependent on factual developments prior to March I96r, and does not account for developments since then.

†Dr. iur. 1945, University of Padua (Italy). Manager of the Finance and Treasury Department of the European Investment Bank. Author, LA Banca Europea PER GLI INvestimenti (I957). 
made for reconstruction, investment appeared clearly inadequate. Thus, in 1952, per capita investment (stated in dollars) was $\$ 126$ for the six Community countries as a whole, whereas in the same year in the United States it was $\$ 314$. This deficiency was particularly felt in the basic industry sectors, which were affected more than the others by wartime destruction and the aging of installations. Independently even of the creation of a common market for the products of the coal and steel industry, an energetic policy of investment was from that time necessary in order to improve productivity. This effort to obtain new investment became even more indispensable with the creation of a common market for coal and steel, which implied increased competition and, therefore, an added need to modernize equipment, specialize activities, and concentrate production in order to reduce costs.

If accelerated investment was avowedly indispensable for E.C.S.C. enterprises, it was still necessary to make this investment possible by providing adequate financial means. Furthermore, it was indispensable that this adaptation to the new and more stringent competitive conditions created by the common market not be realized at the expense of the workers through reduction of employment and a worsening of working conditions.

The arduous task thus given to E.C.S.C. was to ensure the most rational allocation of production at the highest level of productivity, and at the same time, to safeguard continuity of employment and avoid the creation of fundamental and persistent disturbances in the economic systems of the member countries. Accomplishment of this task required efficacious intervention at the Community level in the promotion of investment and of technical and economic research, as well as in assistance to workers affected by the progressive establishment of the common market.

\section{B. Field and Means of Action}

The field of action which the Treaty establishing the E.C.S.C. has laid down for its executive, the High Authority, is vast and covers the Community's whole sphere of action. With respect to financing activity, in the true sense, the High Authority may grant loans or guarantees:

(a) to facilitate the financing of industrial investments in the coal and steel industries;

(b) to facilitate the financing of the construction of housing for the workers in these industries;

(c) to facilitate the financing of investments which do not relate to Community enterprises, on the condition that they help directly and essentially to increase production, lower production costs, or facilitate the disposal of products subject to the jurisdiction of the High Authority;

(d) to facilitate the financing of the creation of new jobs for the benefit of workers set free by technical progress or by the consequences of the establishment of the common market. 
Furthermore, the High Authority may give grants or loans:

(a) to facilitate the "readaptation" of workers set free by the establishment of the common market, by technical development in the coal or steel industry, or as a result of structural modifications in the marketing conditions in those industries;

(b) to encourage technical or economic research relating to the production of coal and steel and the development of their use, as well as to the security of workers in those industries.

This is the field of action of the High Authority. The financial means at its disposal on venturing into this field arise principally from two sources-its own taxing power and borrowed funds. Of course, these two categories of resources are not interchangeable. Money borrowed by the Authority can, in fact, only be utilized in granting loans-and not to meet administrative expenses or to grant monetary assistance which is not reimbursable. The resources arising from the Authority's taxing power can be used only within the Treaty's definite limits, which do not include the grant of loans to enterprises. Finally, the High Authority has certain other incidental revenues derived from interest on bank deposits and from other sources, including monetary fines and penalties imposed on enterprises for violation of the E.C.S.C. Treaty or of the High Authority's decisions.

\section{The Taxing Power of the High Authority}

The treaty creating the E.C.S.C. recognizes the right of the High Authority to impose on the enterprises subject to its jurisdiction a levy calculated on the value of the production of coal and steel in the six countries of the Community. This levy is paid monthly by the enterprises on the production realized by them and is calculated at a rate which may not exceed one per cent of the average value of that production. If necessary, and subject to the authorization of the Council of Ministers of the E.C.S.C., the rate could even be fixed above one per cent. We see here the first example of a European tax which the High Authority, by virtue of its own decision and without soliciting any specific authorization either from the Member States or from the other Community institutions, can levy to meet its needs.

To give an idea of the dimensions of the High Authority's taxing power by virtue of this levy, it suffices to say that the value of all Community products subject to the levy totaled about $\$ 8.9$ billions ${ }^{1}$ in the fiscal year ended June 30, rg6o. Thus, the taxing power of the High Authority amounts at the present time to nearly $\$ 89,000,000$ a year. In fact, the High Authority has never applied the ceiling rate of one per cent; and at present the rate in force is 0.35 per cent, which is well below

\footnotetext{
${ }^{1}$ Except as otherwise specified, all amounts in this article are expressed in American dollars and represent either American dollars or their equivalent in the national currency of one or more member countries or in Swiss francs, at the following exchange rates: One American dollar equals 50 Belgian franics, 4.93706 French francs, 4.20 West German marks, 50 Luxembourg francs, 3.80 Dutch guilders, 625 Italian lire, and 4.29 Swiss francs.
} 
the ceiling. The proceeds of the levy were approximately $\$ 3 \mathrm{r}, 000,000$ during the fiscal year ended June 30 , 1960 .

In accordance with the Treaty, the proceeds of the levy are intended to cover:

(a) the administrative expenses of the institutions of the Community;

(b) grants or loans which the E.C.S.C. may make for "readaptation" of workers and for technical and economic research, as mentioned above;

(c) any part of the interest and principal payments due on funds borrowed by the High Authority which are not covered by repayments received by the High Authority on the loans which it makes to the enterprises, and any payments required to be made by the High Authority under any guaranties which it may grant for loans obtained directly by the enterprises.

Thus, it is not unreasonable to assert that the taxing power of the High Authority constitutes the primary basis of its credit.

\section{The Guarantee Fund}

From the outset of its activity the High Authority decided to put a large portion of its taxing power to immediate use by setting up a guarantee fund destined to cover eventual defaults or delays of payment in the loan and guarantee operations of the Community. It may well be questioned whether the establishment of this guarantee fund was really necessary since the High Authority can, at any moment and by its sole decision, increase the rate of the levy in order to face up to its obligations to its lenders and since, in addition, the mere decision of the High Authority to create a guarantee fund confers no privilege whatsoever on those lenders as to the fund thus reserved. If, however, the financial structure of the High Authority is closely examined, the opportuneness of the creation of this fund appears evident. In fact, it has a double objective since:

(a) the existence of this provision is the best assurance of the punctuality of the High Authority in servicing its borrowings for, if the Authority had to wait for defects in payment to appear in order to increase the rate of the levy, the punctuality essential to its credit would risk being compromised; and

(b) The High Authority thus avoids the necessity of having recourse to a sudden increase in the rate of levy to meet important losses in the servicing of loans. (Such a sudden increase would be inopportune for, if such losses were to occur, it would probably be by reason of a general crisis in the coal and steel industry, at which time greater difficulty would arise in paying the surcharge.)

The total of the guarantee fund amounts at present to the equivalent of $\$ 100,000,000$; and the High Authority has declared that it does not contemplate for the moment any increase in the fund. In any case it is the policy of the High Authority to maintain a reasonable relationship between the total of the guarantee fund and that of its outstanding obligations, so that the fund should always be in a 
position to protect lenders against every foreseeable interruption in the servicing of loans made or guaranteed by the Authority. The guarantee fund is thus the second basis of the credit of the High Authority.

\section{E. The Act of Pledge}

Following upon the first loan contracted in 1954, the High Authority in the same year concluded with the Bank of International Settlements an agreement (better known as "the Act of Pledge") which is accepted by all the lenders to the High Authority and cannot be modified without their consent. Pursuant to this agreement, the credits of the High Authority and the concomitant securities arising from the loans granted by the Authority out of the monies it has borrowed are included in a separate portfolio placed as a pledge in the hands of the Bank of International Settlements for the benefit of all the lenders to the Authority.

It would take too long to enumerate in detail the provisions of this Act of Pledge, which constitute for Europe a somewhat original formula. For the objects of the present study, it is sufficient to indicate the more important consequences of this common pledge. First of all, the pledging of the credits held by the High Authority has the effect of placing its lenders in a privileged position in relation to all the other creditors of the Authority. Furthermore, by reason of this common pledge none of the lenders has, nor can have, any private rights over any category whatsoever of the credits representing loans granted by the Authority, whatever the currency of those loans. The combined group of lenders has as a guarantee the combined group of credits of the High Authority arising from loans made to enterprises by the Authority. Finally, it is the Bank of International Settlements which, on the instructions of the High Authority and after having assured itself that these instructions comply with the provisions of the Act of Pledge, receives the funds borrowed and pays out the sums loaned. The Bank also receives, as they fall due, the annual payments owed to the Authority by the borrowing enterprises and pays out, as they fall due, the sums due from the Authority to its lenders.

This security accorded to lenders, which is added to the assurances implicit in the taxing power of the High Authority and in the existence of an important guarantee fund, is not so superfluous as it might at first sight appear. In fact, it must not be forgotten that the High Authority is neither a bank nor an institution whose sole activity consists in the grant of credits. It is a complex institution with numerous characteristics of governmental power; and its field of action is vast, entailing the use of its resources for very differing ends. Furthermore, if it is true that its taxing power is very wide, it is also true that such power is not unlimited and could, at least theoretically, be reduced by modifications of the Treaty. Finally, the duration of the Treaty creating E.C.S.C. was fixed for a period of fifty years. Again, theoretically, the possibility arises that at the end of this period the member countries may decide to dissolve the Community or, at least, radically change it. Therefore, the creation of a separate portfolio as to which lenders to the High Authority will have 
a privileged right for the satisfaction of their loan represents not merely a superfluity but, on the contrary, a third essential foundation for the credit of the High Authority.

\section{F. Loans for Industrial Investments}

It has been seen that the treaty establishing the E.C.S.C. outlines only in very general terms the objects for which the High Authority may grant loans. Hence, since the annual investment needs of the Community's coal and steel industries far exceed the funds which the High Authority could hope to place at their disposal by its borrowing policy, the High Authority has been confronted with the problem of establishing criteria for the selection of the projects to be financed. Such criteria could evidently not be purely financial. In fact, the very nature and purpose of the Community were opposed to any choice made solely on the basis of the best risk, the E.C.S.C. being a supranational public institution charged with the duty of fostering the balanced development of these basic industries. The High Authority, moreover, had among its numerous tasks that of periodically defining and publicizing general objectives for the development of the coal and steel industries to ensure that the requirements for the Community in future years will be met and for the modernization of production facilities, enlargement of capacity, and increase in efficiency of operations. It is in these general objectives that the High Authority finds criteria for the selection of projects to be financed.

For loans granted up to now, the High Authority has recognized a claim for priority in the following categories of capital investments:

(a) modernization and mechanization of coal mining installations, including coking plants;

(b) expansion of pithead power stations for consumption of low grade coal;

(c) expansion of facilities for the production and dressing of iron ore;

(d) increase in production of pig iron and coke in order to lessen consumption of scrap;

(e) construction of new manufacturing facilities and other projects providing productive employment for workers unemployed because of the coal crisis.

After a first selection of projects has been made pursuant to these criteria, the final decision of the High Authority is based on financial criteria; and the only projects eventually retained are those exhibiting the desired characteristics of profitability, the borrowers giving every guarantee of solvency. The principal conditions of the loan contracts are these:

(a) The rate of interest is fixed in relation to the cost to the High Authority of the corresponding money borrowed, with the sole addition of the expenses and commissions involved in the administration of the Act of Pledge. The High Authority, which has no profit goal in view, has renounced the seeking of any marginal profit on its loans, although the treaty gives it that 
option. The rate of interest is the same for. all loans granted out of any particular sum borrowed, whatever the nationality of the borrower or the nature of the project.

(b) The period of repayment of the loan is fixed in relation to the time for repayment which the High Authority itself obtained for the corresponding sum borrowed.

(c) The security demanded varies in each case according to the nature of the project and the situation of the borrower and in conformity with banking custom.

(d) Finally, the loan is made and is reimbursable in the same currency as that which applies to the corresponding sum borrowed. Thus it is the beneficiaries of the loans who bear any subsequent exchange risks.

\section{G. Loans for Financing the Construction of Workers' Homes}

From the commencement of its activity, the High Authority has realized the importance of housing workers with a view to the amelioration of their conditions of life and work. It has, therefore, decided to provide substantial means of financing for the realization of programs of construction of houses destined for coal and steel workers.

For such financing it was impossible to place the burden of exchange risks on the borrowers, and it was, therefore, necessary to grant loans in the respective national currencies. Furthermore, account had to be taken of the fact that the profitability of workers' houses in the Community countries was generally too limited to remunerate capital at the high interest rate applicable in most of the national financial markets. Faced with these difficulties which threatened the effectiveness of its financial aid, the High Authority decided to allocate to the financing of housing a special reserve supported by the resources arising out of any net profit derived from investment of the levy funds. By adding to these resources, lent at reduced rates of interest, other capital obtained or mobilized in accordance with market conditions, the High Authority has been able to place credits at the disposal of the borrowers at the rates usually in force in each of the Community countries for the financing of workers' houses.

H. The Financial Results of the Activity of the High Authority

Although the Treaty setting up E.C.S.C. came into force in July 1952 , it was the year I954 which marked the real commencement of the High Authority's financial activity. In the spring of that year, in fact, the United States Government signed a contract with the High Authority whereunder, with the Export-Import Bank as intermediary, a credit of $\$ 100,000,000$ was accorded to the High Authority.

The liability for loans thereafter contracted by the High Authority amounted on December 3I, I960, to about $\$ 250,000,000$. Of this amount, $\$ 20,000,000$ arose from three public issues in the United States market and about $\$ 11,600,000(50,000,000$ Swiss francs) from a public issue offered in Switzerland in 1956 . On the other hand, 
no public issue has been made in Community countries. The balance arises from the loan by the United States and from other loans arranged with specialized organizations in Community countries and allocated to financing workers' houses. The breakdown of these borrowings is shown in detail in the following table:

\begin{tabular}{|c|c|c|c|c|}
\hline \multirow[b]{2}{*}{ Country } & \multirow[b]{2}{*}{$\begin{array}{l}\text { Year of } \\
\text { Issue }\end{array}$} & \multirow[b]{2}{*}{$\begin{array}{c}\text { Original Amount of } \\
\text { Ioan }\end{array}$} & \multicolumn{2}{|c|}{ EquTValent in U. S. Doldaks } \\
\hline & & & Original Amount & $\begin{array}{c}\text { Outstanding } \\
\text { December 31, } 1960\end{array}$ \\
\hline \multirow[t]{2}{*}{ 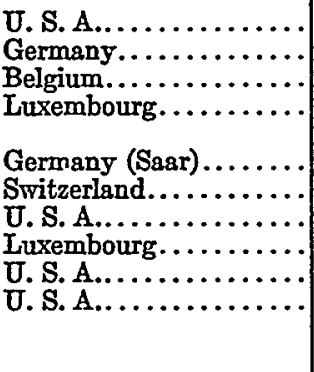 } & \multirow[t]{2}{*}{$\begin{array}{l}1954 \\
1955 \\
1955 \\
1955 \\
1956 \\
1956 \\
1957 \\
1957 \\
1958 \\
1960\end{array}$} & \multirow[t]{2}{*}{$\begin{array}{lr}\$ & 100,000,000 \\
\text { DM } & 50,000,000 \\
\text { FB } & 200,000,000 \\
\text { Flux } & 5,000,000 \\
\text { FB } & 20,000,000 \\
\text { DM } & 2,977,450 * \\
\text { FS } & 50,000,000 \\
\$ & 35,000,000 \\
\text { Flux } & 100,000,000 \\
\$ & 50,000,000 \\
\$ & 35,000,000 \\
& \\
& \text { Total. . . . . . . }\end{array}$} & $\begin{array}{r}100,000,000 \\
11,904,762 \\
4,000,000 \\
100,000 \\
400,000 \\
708,923 \\
11,655,012 \\
35,000,000 \\
2,000,000 \\
50,000,000 \\
35,000,000\end{array}$ & $\begin{array}{r}90,8(10,000 \\
10,627,452 \\
3,688,000 \\
368,800 \\
638,734 \\
11,656,012 \\
31,700,000 \\
2,000,000 \\
50,000,000 \\
35,000,000\end{array}$ \\
\hline & & & $250,768,697$ & $236,477,998$ \\
\hline
\end{tabular}

- Upon the economic integration of the Baar with the Federal Republic of Germany in July 1959, the outstanding amount of guch loan ras converted at the then official rate from French francs to Deutsehmarks.

Also as of December 3I, I960, the High Authority had granted loans out of borrowed funds and prepayments on loans in a total amount of about $\$ 260,790,000$. In addition, it had granted out of its own funds loans totaling about $\$ 30,000,000$. The division of the loans granted according to the capital investments financed and among borrowers in the various member countries is shown in the following table, the figures being in millions of dollars.

\begin{tabular}{|c|c|c|c|}
\hline Division of Loans & $\begin{array}{c}\text { Loans from } \\
\text { Borrowed Funds }\end{array}$ & $\begin{array}{c}\text { Loans from Funds } \\
\text { not Borrowed }\end{array}$ & Total \\
\hline \multirow[t]{2}{*}{ 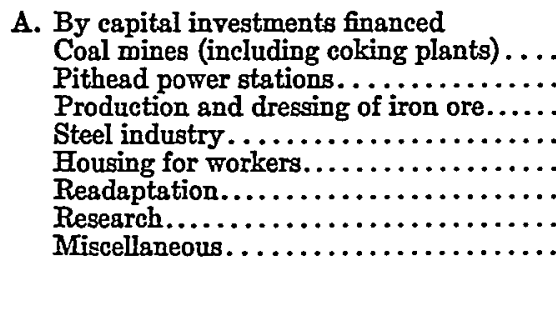 } & $\begin{array}{l}88.14 \\
46.31 \\
22.25 \\
83.98 \\
20.11 \\
= \\
=\end{array}$ & $\begin{array}{l}\bar{Z} \\
\bar{z} \\
21.68 \\
5.40 \\
2.88 \\
0.72\end{array}$ & $\begin{array}{r}88.14 \\
46.31 \\
22.25 \\
83.98 \\
41.79 \\
5.40 \\
2.88 \\
0.72\end{array}$ \\
\hline & 260.79 & 30.68 & 201.47 \\
\hline \multirow[t]{2}{*}{ 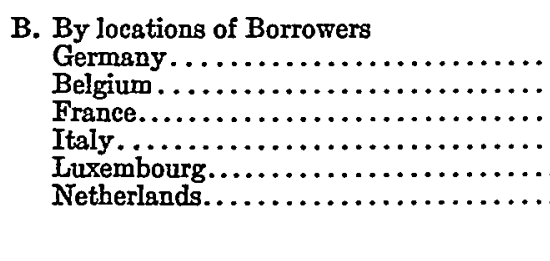 } & $\begin{array}{r}135.98 \\
27.20 \\
55.86 \\
40.45 \\
1.30 \\
-\end{array}$ & $\begin{array}{r}22.06 \\
1.06 \\
4.13 \\
1.14 \\
1.01 \\
1.28\end{array}$ & $\begin{array}{r}158.04 \\
28.26 \\
50.90 \\
41.50 \\
2.31 \\
1.28\end{array}$ \\
\hline & 260.79 & 30.68 & 201.47 \\
\hline
\end{tabular}


The outstanding loans at the same date amounted to $\$ 238,200,000$. In addition, the High Authority guaranteed loans contracted by enterprises up to a total of about $\$ 10,000,000$.

To this report of more strictly financial activity must be added some information relating to assistance granted by the High Authority in connection with "readaptation" and technical and economic research. Up to December $3 \mathrm{r}$, 1960, the aggregate commitments that had been contracted by the High Authority for "readaptation" amounted to the equivalent of $\$ 52,500,000$. A total of $\$ 29,500,000$ having already been paid out, the net commitments as of that date were about $\$ 23,000,000$. The commitments contracted by the High Authority in connection with research amounted at the same date to the equivalent of $\$ 28,000,000$. A total of about $\$ 13,000,000$ having been paid out, the net commitments amounted to $\$ 15,000,000$.

These few figures should suffice to demonstrate the importance of the financial activities of E.C.S.C. The High Authority started its activities at a time when the industries placed under its jurisdiction suffered from a penury of long-term capital and the capital markets of nearly all the Community countries offered only limited sources of capital and at particularly high rates. There is no doubt that the High Authority has effectively contributed to making possible the necessary capital investment which, without its action, would not have been realized or would have been realized later. The High Authority is a recently-created juridical entity, new and complex in form, whose constitution, powers, functions, and financial situation were first almost unknown to the public; but it has rapidly succeeded in obtaining access to the international capital markets, and notably to that of the United Statesmarkets which had been very cool to foreign borrowers due to past unfortunate experiences of the lenders. Finally, the happy results attained by the Authority in the sphere of assistance for readaptation and research have not failed to furnish particularly useful experience for the analogous mechanisms brought into action in the two new European Communities.

\section{II}

\section{The European Community of Atomic Energy}

\section{A. Its Tasks}

The Treaty setting up the European Atomic Energy Community, better known as Euratom, indicates that its mission is, by establishment of the conditions necessary for the formation and rapid growth of the nuclear industry, to contribute to raising the standard of life in the member countries and to the development of exchanges with other countries. Nuclear energy presents itself as an essential resource in the future for the development and maintenance of production and for industrial progress of peaceful enterprises; a new technical revolution is awaited as to the use of this new source of energy. Hence comes the urgency for the Community countries to overcome their backwardness in this sphere, in order to assure that their role in these developments. is not seriously compromised. 
However, the necessary means are no longer available to the separate European countries; therefore, Euratom proposes to unite the resources of the Member States in a common effort to permit a production of nuclear energy which each of them working alone would have found it difficult to realize. The common use of the resources, scientific as well as technical and economic, in existence in the six countries was really the only way to achieve that aim and avoid dispersion and waste of energy in enterprises competing among themselves and often superfluous.

Euratom is a specialized Community and represents in the sphere of nuclear energy what E.C.S.C. represents for the coal and steel industry. But E.C.S.C., as the first of the European Communities to see light-and solely because of its earlier appearance on the scene-was equipped with fairly wide powers even in fields (such as labor problems) which are outside the scope of the basic industries. On the other hand, Euratom, born at the same time as E.E.C., finds its powers more strictly limited.

Among the tasks allotted to Euratom, the following seem susceptible of involving financial activity:

(a) developing research;

(b) facilitating investments and ensuring, particularly by encouraging business enterprise, the construction of the basic facilities required for the development of nuclear energy within the Community;

(c) ensuring a regular and equitable supply to all Community users of ores and nuclear fuels.

\section{B. Field and Means of Action}

Article four of the Euratom treaty allocates to the Euratom Commission the task of promoting and facilitating nuclear research in Member States and carrying it to completion by the execution of a program of research in the Community. To carry out this task the Commission:

(a) is to create a common center of nuclear research;

(b) may entrust third parties with the implementation of certain parts of the Community's research program;

(c) may encourage research programs undertaken by third parties by giving financial support in the form of loans, by supplying or providing-either for payment or free of charge-raw materials or fissionable substances, as well as installations, equipment or expert assistance.

As regards action in the investment sphere, the Commission may either grant loans or participate directly in the financing of enterprises which it recognizes as having outstanding importance for the development of nuclear energy in the Community and which, for this reason, may be constituted as Joint Enterprises in accord with article forty-five of the Euratom Treaty.

Finally, as regards the supply of ores and nuclear fuels, the Treaty has provided 
for the creation of a Supply Agency having a right of option on all ores, raw materials and special fissionable substances produced in the territories of the Member States, and having, furthermore, the exclusive right of concluding contracts relating to the supply of these same materials issuing from within or without the Community.

\section{Its Resources}

In examining the resources at the disposal of Euratom to meet its obligations, distinction must be made between expenditure for operation and research, the financing of research and investment, and the activity of the Supply Agency. The costs of operation and of research are a charge on the Member States of the Community and are based on the budget prepared each year by the Council of Ministers according to the following scale of division:

$\begin{array}{lcc}\text { Country } & \text { Operational Budget } & \begin{array}{c}\text { Research and } \\ \text { Investment Budget }\end{array} \\ \text { Belgium } & 7.9 \% & 9.9 \% \\ \text { Germany } & 28 & 30 \\ \text { France } & 28 & 30 \\ \text { Italy } & 28 & 23 \\ \text { Luxembourg } & 0.2 & 0.2 \\ \text { Netherlands } & 7.9 & 6.9\end{array}$

In contrast to E.C.S.C., Euratom does not enjoy financial autonomy. It is true that article $x_{73}$ of the Treaty leaves the door open for the establishment of a levy which Euratom would collect in the Community, the proceeds of which would be destined to replace in whole or in part the financial contributions of the Member States. However, the establishment of such a levy is only a possibility, since the Member States are by no means committed to taking any such action. Therefore, at least in the present state of the Treaty, the autonomy of resources which constitutes the primary basis of E.C.S.C. credit does not exist in the case of Euratom.

For the financing of research and investment, the Treaty endows Euratom with borrowing powers, but here again a difference can be seen between the provisions which govern the borrowing activity of E.C.S.C. and those laid down for Euratom. In fact, the High Authority of E.C.S.C. is alone competent to undertake borrowing, as well as to grant loans. On the contrary, for Euratom the power of decision in borrowing matters resides in the Council of Ministers on the basis of proposals from the Commission. This concentration of the powers of decision on financial matters in the hands of the Council of Ministers, which consists of representatives of the Member States, is the logical consequence of the financial structure of Euratom. In fact, since Euratom has no resources of its own, the Member States are the ones who finally would have to face up to its obligations in case the financing arrangements made by Euratom proved insufficient to meet its debts. Hence, it appears 
natural that the Member States should have reserved the right to decide on the exercise of borrowing powers. It may, however, be questioned whether the somewhat intricate procedure resulting from the necessity of a Council decision is the most appropriate one for an institution like Euratom which is supposed to procure part of its resources by floating loans on the capital markets.

This financial autonomy, which Euratom lacks, exists, on the other hand, in the case of the Supply Agency (which is likewise endowed with juridical personality) although the Agency is subject to the control of the Euratom Commission, which has, notably, a right of veto over Agency decisions. The Agency capital is equivalent to $\$ 2,400,000$ and has been subscribed by all Member States except Luxembourg. Of this total, ten per cent has been paid up, and the balance may be called in as necessary to meet the obligations of the Agency. Moreover, the Agency may levy a charge on the transactions within its jurisdiction-a charge which can serve only to defray its operating expenses. In fact, the Agency has so far avoided recourse to levying this charge, and its expenses have been financed by the Community's budget of operations. Finally, the Agency may resort to borrowing in order to procure the resources necessary for the accomplishment of its tasks. These borrowings, which are guaranteed by Euratom, may not, however, be undertaken without the consent of the Commission and of the Council of Ministers.

\section{Its Activity}

The time gone by since the dates of entry into force of the Euratom Treaty and of the establishment of that Community's institutions is surely too short to permit an evaluation of the results of its activity in the financial sphere, a sphere wherein somewhat prolonged preparation is natural before operations can begin. However, attention may be drawn with satisfaction to one early financial operation of wide scope already undertaken by Euratom in the second year of its activity and whose realization will be spread out over several years. In the framework of a cooperation agreement between Euratom and the United States, the latter, through the ExportImport Bank, has placed funds at the disposal of Euratom, by opening a credit of $\$ 35,000,000$, which Euratom may use in order to make a contribution to the financing of the construction, on Community territory, of nuclear centers. These centers are to be of the same types as those in which research and development have been pushed to an advanced stage in the United States. They will have a total installed capacity of about $r, 000,000$ kilowatts.

The situation which has arisen in the energy market in the last few years makes nuclear energy more costly than classic energy and has had the effect of slowing down the final approval of projects for centers capable of being financed within the framework of the agreement with the United States. For that reason, no loan has yet been made by Euratom, although projects are now being studied. This delay, however, in no way detracts from the importance of the agreement-which demonstrates once more the active interest the United States takes in the progress of European unification and, at the same time, its confidence in this new Community. 
As regards the field of research, the creation of a Joint Research Center was delayed due to complex negotiations between Euratom and the Member States. Nonetheless, it can be estimated that effective commitments by Euratom within the framework of the Community's first five year program of research will reach at the end of $196 \mathrm{r}$ the total amount of $\$ 104,000,000$ and that disbursement on these commitments will reach at the same time the amount of $\$ 78,000,000$.

Finally, as regards the Supply Agency, neither a shortage of ores and raw materials has so far been encountered nor a change in the good prospects for obtaining special fissionable substances necessary for Euratom. Thus, the Agency's task has momentarily been reduced to guaranteeing good supply conditions, without: involving any financial operations in this respect. But the activity of the Agency will be quickly developed in the future with the extension of the research programs: and the construction of nuclear centers.

III

\section{The European Economic Community}

A. Its Tasks

Of the three existing Communities, the European Economic Community is undoubtedly the one which has the greatest task to accomplish. Its objective is to build up a common European market-and so to call into life a vast zone of common economic policy, constituting a powerful unit of production and permitting continuous expansion, increased stability, accelerated elevation of the standard of life, and the development of harmonious relations between the component states.

The mere list of these objectives is sufficient to understand the amplitude of the tasks of the E.E.C., whose powers extend from the free circulation of goods to the establishment of a common agricultural policy; from the free circulation of persons, resources and capital, to the means of transport and rules of competition; from thecoordination of the economic, financial and commercial policies of the member states, to social policy, and last but not least, to assistance to underdeveloped countries.

\section{B. Field and Means of Action}

In spite of the amplitude of its tasks and responsibilities, the E.E.C. is, of the three European Communities, the one whose financial activities are the most limited. In fact, although the problem of the investment policy in the Community figures. among those calling particularly for attention by the E.E.C., its role in this spherecomprises tasks of coordination, supervision, orientation, and sometimes even of promotion of projects; but it does not include either the financial activity or responsibility of the Community organs.

The task of lending financial aid to investments, the accomplishment of which is recognized to be of importance for the balanced development of the common market, has been entrusted to another organization, the European Investment Bank. Although originating in the same Treaty of Rome which created the E.E.C. andi 
working in close cooperation with that Community, the Bank is endowed with its own juridical personality and with complete autonomy vis-à-vis the E.E.C. as to both decisions and resources. Analysis of the structure and activities of the Bank will form the subject of a separate section in this article, wherein at the same time the role played in this sphere by the E.E.C. Commission will be examined. There remain, however, to be examined here two other areas in which the E.E.C. engages in direct financial activity-namely, the "readaptation" of workers and assistance to overseas countries.

Article I23 of the Treaty of Rome provided for the creation of a European Social Fund, having as its mission the promotion of employment opportunities within the Community and of workers' mobility, both geographic and occupational. This Fund is administered and directed by the E.E.C. Commission, assisted in this task by a committee formed of representatives of Member States and unions or workers and employers. The fundamental objective of the Fund is to prevent prejudicial consequences to labor as a result of the progressive establishment of the common market; however, the Fund is not supposed to intervene in cases where only unemployment is a consequence of the common market. This is a substantial difference from the mechanism of "readaptation" provided for by the E.C.S.C. Treaty; and this difference needs to be underlined because it involves considerably extended tasks for the Fund.

The Fund is in fact called upon to cover fifty per cent of the expenses incurred by a Member State or by a body under public law in the three following casesprofessional reeducation of unemployed workers, relocation of those workers, and maintenance of the same wage level for workers affected by conversion of their enterprise to other production. As the Social Fund enjoys neither juridical nor fiscal autonomy vis-à-vis the E.E.C., its expenses are a charge on the E.E.C.

A Convention annexed to the E.E.C. Treaty relating to the Association with the Community of the Overseas Countries and Territories implemented the constitution of the Development Fund for the overseas countries and territories which formerly were colonies or possessions of Member States. The aim of this Fund is to have the Member States participate in measures designed to achieve the social and economic development of these countries in an effort exceeding the one of their responsible authorities. The limits of activity of the Development Fund are clearly fixed, and in that respect it differs from the Social Fund. Both are limited, however, to nonreimbursable assistance. The Development Fund is to be supported by contributions that the Member States have undertaken to make during a period of five years. The amount of this contribution is divided up as follows: $\$ 70,000,000$ from Belgium; $\$ 200,000,000$ from Germany; $\$ 200,000,000$ from France; $\$ 40,000,000$ from Italy; $\$ 1,250,000$ from Luxembourg, and $\$ 70,000,000$ from the Netherlands.

The funds available must be utilized in financing projects in the overseas countries and territories, former colonies, or possessions of the Member States according to the following scale: Belgium, $\$ 30,000,000$; France, $\$ 511,250,000$; Italy, $\$ 5,000,000$; the 
Netherlands, $\$ 35,000,000$. It falls to the Council of Ministers to fix each year the amount destined to finance social institutions (schools, hospitals, etc.) or economic investments (mainly infrastructural projects). It falls to the Commission to choose the individual projects to be financed. However, as regards economic investments, each Member State has the right of insisting that individual projects be submitted to the Council of Ministers.

\section{Its Resources}

Like Euratom, E.E.C. has no resources of its own and its expenses are covered by contributions which the Member States make each year on the basis of the budget fixed by the Council of Ministers. The E.E.C. Treaty contains, however, a provision analogous to that found in the Euratom Treaty, by virtue of which the Commission is charged with studying the conditions under which the contributions of Member States could be replaced by other sources of funds-notably by receipts arising from the common customs tariff when such a tariff has been definitely established. However, the powers of the Commission in this field are limited to the submission of proposals to the Council of Ministers; and it is only by unanimous vote that the Council, after consultation with the Assembly, could eventually formulate proposals which it would recommend that the Member States adopt in accord with their respective constitutional rules.

Although the problem of endowing the Communities with their own financial resources is always important-notably because of the influence that autonomy of resources can have in the relations between the Executives of the Communities and the Member States-nevertheless, from the strictly financial point of view this need to possess its own resources is less evident in the case of E.E.C., which, since it does not have to borrow, is not confronted with a need to establish a sound basis for obtaining credit.

Division of the financial contributions required from the Member States differs according to whether the contributions are for operational expenses or for the Social Fund.

$\begin{array}{lcc}\text { Country } & \text { Operational Expenses } & \text { European Social Fund } \\ \text { Belgium } & 7.9 \% & 8.8 \% \\ \text { Germany } & 28 & 32 \\ \text { France } & 28 & 32 \\ \text { Italy } & 28 & 20 \\ \text { Luxembourg } & 0.2 & 0.2 \\ \text { Holland } & 7.9 & 7\end{array}$

D. Its Activity

The institutions of the E.E.C. were set up only at the beginning of 1958 -at the same time as those of Euratom. Despite that, their early years of activity in the progressive establishment of the common market were distinguished by results 
largely outstripping the most optimistic forecasts. On the other hand, progress was necessarily slower with respect to the Social Fund and the Development Fund in view of the need to establish at the outset, with the consent of the Member States, the details of the rules and procedures to govern their activity.

Thus, the regulations for the European Social Fund were not adopted by the Council of Ministers until May II, I960; and, mainly for this reason, no expenditure has yet been made. The activity of the European Overseas Development Fund, on the other hand, developed more rapidly. By December 3I, I960, the Commission had received proposals involving an over-all request for financing equalling $\$ 666,000,000$, allocable, according to their objects, as follows: studies and researches, $\$$ r4,000,000; economic investments, $\$ 499,000,000$; social investments, $\$ 153,000,000$. By the same date the amounts granted for these projects amounted world-wide to $\$ \mathrm{II} 3,000,000$, divided as follows: studies and research, $\$ 8,500,000$; economic investments, $\$ 65,500,000$; social investments, $\$ 39,000,000$.

\section{IV}

The European INVEstment Bank

From the commencement of negotiations between the Member States for the establishment of the European Economic Community, the creation of an investment institution endowed with assured financial resources, and at the same time capable of introducing itself on the capital market as a first-class borrower, has been considered indispensable to assure conditions for a balanced and smooth development of the common market. It is not true, as has been abundantly proved by the experiences of Italy after its unification in 1860 and of the United States after the Civil War, that when regions of unequal economic development are suddenly brought into communication, the lower cost of labor and the greater productivity of investments automatically ensure more rapid progress in the region less favored initially, and thus a general levelling up. On the contrary, the gap may increase cumulatively, if the basic conditions for a universal development of production are not at the outset created by public means and if, besides other facilities accorded by the government, important means of financing are not placed at the disposal of the enterprises desirous of settling themselves in these less-developed regions.

On the other hand, economic reconversion constitutes an essential element of the policy of the common market. It is not enough to consider the enlargement of outlets and of competition as a sufficient incentive to enhance the reorientation of industrial activities and the modification of production methods. In addition, it is necessary that the enterprises, forced to modify methods by the progressive disappearance of protectionism, should be able to find financing for these changes; thus, the need to lend financial help is obvious. Industrial reconversion and the opening of new activities capable of providing employment for workers, figure among the tasks which are of the greatest social and economic utility. Their benefits cannot be measured solely by their direct effects nor by the existing facilities which 
they manage to use or save, but rather by the climate of progress and transformation which they help to create.

Finally, the establishment of the common market embraces the realization of projects, which by reason of their scope, or even simply their very nature, do not qualify easily for the various sources of capital available in each of the different member countries. The most typical projects of this kind will occur in the field of communications and the production or transport of energy. From the moment that European interest is attested by the number of countries concerned with a project or associated with it, a Community source normally should be provided for its financing.

Article 130 of the Treaty establishing the European Economic Community has confided to the European Investment Bank the mission of granting loans or financial guarantees for projects to develop underdeveloped regions, modernize enterprise, or create new activities called for by the progressive establishment of the common market. The same applies to projects of common interest to several of the member countries, but which cannot be financed by means available in each country.

In order to achieve these aims, two solutions can be envisaged: creation of a financial institution of bank character or the setting up of an assistance fund. Two different categories of development loans correspond with these two solutions. In the first category stand loans which offer to the borrower more favorable conditions than those of the financial markets in regard to rate of interest, term of the loan, and other accessory matters. Such loans, called "soft loans," are necessary in the case of investments which-while constituting a sort of first step on the road to economic development or being indispensable to the launching of a process of cumulative development-do not offer the desired financial profitability. Thus, the financial servicing of these loans by the borrower cannot be secured unless their rate of interest is fixed considerably below the market rate. These loans cannot be granted by bank-type institutions but fall, by contrast, within the scope of financial assistance funds, which have their resources more or less directly in the contributions of the participating States. Examples of institutions of this kind can be found in the Development Loan Fund, the International Development Association, and-on the European scale-in the Development Fund for Overseas Countries and Territories.

In the other category are loans of the banking type. These loans are suitable for self-liquidating investments, which offer the desired financial profitability and thus offer secured financial servicing in accordance with normal market conditions. These loans come within the scope of financial institutions of the banking type, which draw the essential bulk of their resources from the financial market, and for which the quality of these investments constitutes one of the principal bases of their own credit. Examples of simliar financial institutions on the international scale are the International Bank for Reconstruction and Development and the International Finance Corporation. Under this same heading can also be included the financial activity of E.C.S.C.-although this body not only grants "self-liquidating" loans for industrial 
investments, but also others to finance workers' houses, which then have the characteristics of "soft loans." The European Investment Bank also comes within the category of financing institutions of the banking type. Moreover, simply by reading its statute, which forms an integral part of the Treaty setting up E.E.C., it is evident that the Investment Bank has all the characteristics of that category.

\section{A. Its Structure}

The European Investment Bank, as has been seen, was created within the framework of the E.E.C.; but it has its own juridical personality, its own means of financial action, and its own organs of operation. This autonomy and independence of the Bank are inherent in its nature as a banking institution called upon to obtain essential means of action from the financial markets; and these factors constitute the best guarantee to lenders of the Bank's capability to act as a real credit institution-without being conditioned by political considerations and yet being inspired by the economic policy and goals of the Community.

The capital of the Bank amounts to a billion units of account; and this unit has a value of 0.88867088 grams of pure gold, which is the par in gold of the American dollar. The breakdown of the capital according to the Member States is as follows: Germany, 300 millions; France, 300 millions; Italy, 240 millions; Belgium, 86.5 millions; Holland, 7r.5 millions; and Luxembourg, 2 millions. Of this total of one billion, 250 millions have actually been paid in by the Member States. The balance of $75^{\circ}$ millions has the character of guarantee capital, which can be called in if necessary to meet the Bank's obligations to its lenders. In other words, the Member States are guarantors of the Bank's liabilities up to the limit of their share in the total capital subscribed but not paid up.

Provisions analogous to those governing the International Bank for Reconstruction and Development aim at ensuring the maintenance of the original value of the paid-up capital, in case of modification in the par value of the currencies of the Member States, by a system of adjustments between the Bank and the Member States in question. These provisions fulfill the double objective of assuring (a) that the devaluation of the currency of a Member State will not unbalance the agreed contributions of the Member States to the Bank capital and (b) that the Bank will not sustain unjustified losses.

However, the support given by Member States to the Bank does not stop at that point. In fact, the Bank may approach the Member States in order to obtain special loans, if the market situation would not allow it to procure the necessary resources under convenient conditions. These loans may be demanded in $196 \mathrm{x}$ and thereafter, and may not exceed altogether a total of 400 million units of account or 100 millions in any one year. These special loans are to be granted by Member States in proportion to their subscription to the Bank's capital.

Finally, the Bank will procure the resources necessary for its activity by floating loans on the financial markets within the Community as well as outside. It can be 
pointed out in this connection that the loan and guarantee capacity of the Bank has been fixed by statute at 250 per cent of the subscribed capital-at the present time $2,500,000,000$ units of account. Compared with the paid-up capital, this figure implies a large recourse to sources of outside capital.

The Bank is an institution which does not aim at profit and does not remunerate its capital. All of its net revenues are devoted to creating reserves and provisions. The organs of the Bank are the Board of Governors, the Board of Directors, and the Management Committee. The Board of Governors, composed of ministers designated by the Member States, has functions similar to those exercised by the shareholders at the annual meeting of a private corporation. It is notably this body which defines the general directives for the Bank's credit policy. The Board of Directors, whose members are nominated by the Board of Governors on the recommendation of the Member States and the E.E.C. Commission, is alone authorized to decide on the grant of loans and guarantees and on borrowing by the Bank itself. In addition, it has control of the ordinary administration of the Bank.

The Management Committee, which is composed of the President and two Vice Presidents, is the veritable center of the activity of the Bank. In effect, independent of its statutory powers-the management of current affairs, the preparation of the decisions of the Board of Directors, and their execution-this is the organ in which is vested full power of initiative.

\section{B. Principles of Action}

The provisions of its statute define certain principles to be followed by the Bank in granting loans and guarantees. These principles may be summed up as follows:

(a) the financial aid of the Bank can be sought by the Member States as well as by any enterprise or institution, public or private, operating in any sector whatever of the economy. Requests for financing may be made direct to the Bank, or through a Member State or the E.E.C. Commission;

(b) the Bank may finance only investment projects which contribute to the increase of economic productivity in general and favor the establishment of the common market; the financial soundness of the project must be assured by the earnings when the enterprise to be aided is in the sector of production, and for other projects the interest and amortization of the loan must be guaranteed by an obligation of the State in which the project is carried out or by any other means;

(c) the projects to be financed normally must be situated in the territory of the Member States, but under special procedures the Bank may also finance projects in third party countries;

(d) the Bank grants financial aid in so far as other sources are not available on reasonable terms; and, so far as possible, the granting of its loans is subject to employment of other means of finance. Thus, instead of competing with the existing banking system, it complements that system; 
(e) unlike the International Bank for Reconstruction and Development, the European Investment Bank is not obliged to make the grant of a loan subject to a guarantee from a Member State; it has the right to choose the required guarantees in conformity with banking custom. It must, in any case, include in its loan contracts appropriate protection against exchange risks;

(f) the rate of interest on loans granted by the Bank must be adapted to the conditions prevailing in the capital market and no reduction in rate of interest may be allowed; but if the case so requires, a rebate may be granted the Member State concerned or a third party on the condition that it is compatible with the E.E.C. Treaty.

A detailed procedure is laid down for the approval of requests for loans and guarantees. As to each application for loan or guarantee, after having received the opinion of the Member State interested and of the E.E.C. Commission, the Management Committee submits its own views to the Board of Directors. In practice, the latter cannot grant loans or guarantees for projects as to which either the Management Committee or the Commission of the E.E.C. have made a negative decision. These provisions not only allow a reconciliation between the autonomy of the Bank and the desired parallelism of its policy with that of the E.E.C., but, at the same time, constitute an efficient guarantee against the possibility that exterior pressure might persuade the Bank to grant credits incompatible with its banking character.

\section{Its Activities}

The European Investment Bank was created on January I, 1958, the date of the coming into force of the Treaty establishing the E.E.C., and is now in the fourth year of its existence. In fact, the first year was devoted to its organization; and only in 1959 did its real activity commence. The very uniqueness of the new institution imposed upon it the task of resolving a number of new problems before entering upon the active phase.

The Bank has been confronted with many projects, among which it had to make an especially careful selection, since it could accept only those which conformed to the conditions for giving financial aid as prescribed in the statute of the Bank. Out of the projects submitted to it, the Bank had approved by December 3I, Ig6o, twelve loans for a total amount equivalent to $\$ 93,500,000$. The total cost of the projects financed is estimated at about $\$ 689,000,000$; the Bank's share in their financing has averaged about fourteen per cent and varies between eight per cent and fifty-seven per cent according to the nature and size of the projects. Three new loans were approved in February 196I, bringing the total amount of loans granted to the equivalent of $\$ 120,500,000$.

The loans have been granted for projects located in the following countries:

$\begin{array}{ll}\text { Italy } & \$ 82,400,000 \\ \text { France } & \$ 31,700,000\end{array}$




$\begin{array}{ll}\text { Luxembourg } & \$ 4,000,000 \\ \text { Germany } & \$ 2,400,000\end{array}$

The largest share of the money loaned goes to the less developed regions of the Community.

The loans are distributed by economic sector as follows:

$\begin{array}{lcr}\text { Sector } & \begin{array}{c}\text { Number of } \\ \text { Projects }\end{array} & \text { E.I.B.Loans } \\ \text { Energy } & 5 & \$ 37,600,000 \\ \text { Transport } & 2 & 25,000,000 \\ \text { Iron and Steel } & \mathrm{I} & 24,000,000 \\ \text { Chemicals } & 4 & \text { 19,000,000 } \\ \text { Agriculture } & \mathrm{I} & 9,500,000 \\ \text { Processing industries } & \mathbf{2} & 5,400,000 \\ \quad \text { Total } & \text { I5 } & \$ \$ 120,500,000\end{array}$

With regard to the conditions attached to these loans, the Bank follows the banking practice common to the six member countries for comparable operations. The term of the loans is established according to the nature of the projects financed; it has varied from twelve to twenty years for the loans granted up to the present.

Since it has resources in different currencies and since its borrowers are situated in different countries, the Bank had to consider with particular attention the problem of how to apply to the loans granted by it at any particular time the same rate of interest - no matter what the borrower's nationality may be-and how at the same time to place its borrowers in conditions of substantial equality in relation to exchange risks. At present, the Bank gives its clients the choice between two formulae. Under the first formula, the borrower receives the currencies drawn by the Bankwhich may even include currencies of third party countries, but not his own national currency, and he repays in the same ones that he received. Under the second formula, the borrower receives the currency of whichever of the six member countries he chooses, but then the Bank has the right to decide in which currency of the member countries each instalment has to be repaid. These repayments have to be made according to the par values existing at the time the loan was paid out. The rate of interest varies according to the market situation and depends solely on the monetary formula chosen by the beneficiary. For the loans granted up to the present, the rate of interest has been $5 \%$ per cent for the first formula, and $5^{1 / 4}$ per cent for the second.

It has not been considered opportune to resort to borrowing during the first period of activity, the fraction of subscribed capital paid in having been large enough to meet all the requirements of loans granted up to now. Moreover, payments on loans are spread over the whole period of implementation of projects financed. But the expansion of loans and commitments made by the Bank is bringing nearer the time that it will have to turn to the capital markets for the funds it needs; and doubtlessly the first borrowings by the Bank will take place in rg6r. 


\section{Perspectives}

The European Investment Bank is a new institution, and, although in different ways it bears resemblance to the International Bank of Reconstruction and Development, it is not a reproduction of that Bank on a European scale. Its sphere is certainly less extensive, both from a geographical standpoint and in respect to the nature of the projects to be financed. In addition, at least up to the present time, it has been called upon to operate in countries where the capital market has been relatively normal for many years and where the introduction of foreign currencies is not the essential aspect of financing operations.

Certain criticisms have been made with regard to the Bank's activity, which is considered by some people to have been too limited in terms of loans granted up to the present time. The Bank could easily have avoided such criticisms. Had its executives been anxious to indulge in "window-dressing," they could simply have made a less severe selection among the projects submitted to them. Such a policy would certainly have been popular; but it would scarcely have been wise.

Up to the present the Bank has granted almost all its loans to projects situated in underdeveloped regions. This priority conforms with good judgment and with the directives of its Board of Governors. In these regions, the Bank has chosen, in particular, projects concerning energy and the chemical industry-fields which, from the viewpoint of common economic policy, raise no major problems. The Bank has a mission to accomplish-namely, facilitating European integration within the Community edifice of which it is a part. In order to succeed in this mission, it must harmonize its credit policy with the economic policy of the E.E.C. However, the formulation of that policy is very complex, and time and experience are required to develop precise ideas concerning the action to be taken in several different sectors, such as agriculture and transport. That is the reason why the first loans in these two sectors have been granted by the Bank only in the last few months. Had the Bank financed projects in those sectors before even knowing the general lines of the investment policy desired for the establishment of the common market, it would have failed in its mission by deferring to a facile popularity. Undoubtedly, the prudence with which the Bank has chosen to act will be properly appreciated by those who constitute the real judges of the activity of an investment bank-i.e., the financial markets to which it will have to resort in order to obtain capital and for which the quality of the loans granted will constitute a fundamental basis for evaluating its credit.

The Bank has not yet made any loans in one of its three spheres of action-for modernization or reconversion of enterprises or the creation of new activities called for by the progressive realization of the common market. But that realization has only just started. Although progressing with accelerated rhythm, the abolition of tariffs and quantitative restrictions is not yet sufficient to make its effects feltespecially because the member countries are all passing through a very favorable period of growth. The-real problems of -reconversion are thus attenuated and 
sometimes masked, although they may very well reappear with full vigor when the first economic reversal occurs. In this sphere also, the prudent inception of the Bank will allow it to summon up its resources more easily when their use really becomes necessary.

After all, the evolution of the European and worldwide situation opens up for the Bank new perspectives which were probably not foreseen by the authors of its statute. In fact, the general reinforcement of the economic and financial structures of the member countries in the course of the last few years coincides with a global situation in which all the underdeveloped countries-and that means a large majority of the world population - call with ever-growing insistency upon the industrial countries to adopt measures, and notably a policy of investment, which will reduce the gap which separates the ones from the others. It is impossible to ascertain at the present if, and to what extent, this new situation will be capable of exercising any influence on the Bank's activity. What is certain is that the means at its disposal will never be in excess of its needs.

\section{V}

\section{Conclusion}

At the end of this exploration of the institutions of the European Communities and their financial activities, the reader will probably be under the impression that he is coming out of a labyrinth. All these names of institutions with sometimes analogous activities--High Authority of E.C.S.C., Commissions of Euratom and E.E.C., Social Fund, European Investment Bank-will perhaps appear to him as pieces of a very complicated puzzle. He will perhaps consider that, by eliminating some of these pieces, the construction would have gained in efficiency.

To judge thus would be to forget that European construction is not the work of one day, but the result of journeys interspersed with many stopping-places and reached sometimes with difficulty and not without setbacks. This edifice is far from being finished; sometimes the work is slowed down; sometimes the architects change and make new plans; and the time has not yet arrived for hoisting the framework of the roof-namely, political unification. Nevertheless, the construction is making progress; and, since the communal dwelling is already inhabited, there is no question of leaving it incomplete. It would certainly have been preferable to complete the construction in one single operation. It would have gained in unity of style. But it must be realized that it is often too difficult to bring co-proprietors into harmonious agreement.

To revert to the financial sphere, doubtless if there had been one single European Community, the different financial activities would have been concentrated in one single institution. Today, it is probably too late, and at the same time too early, to proceed with this concentration. It is too late because it is always painful and often unwise to disturb institutions whose credit is affirmed. It is too soon because the reality within which these institutions are called to operate is still too fluid. Doubt- 
less, one day the concentration of the Community's financial activities in one central institution will be a necessity. Meanwhile the best results will be obtained by the ever closer collaboration between the existing different institutions. The problems to be resolved are so vast and the resources so limited that this cooperation will be a natural consequence-cooperation between the High Authority and the Bank for financing basic industries and operations of reconversion; between Euratom and the Bank for financing nuclear energy; between the Social Fund and the Bank for reconversion; between the Development Fund and the Bank for aid to underdeveloped countries. All these institutions have one task in common, namely, the construction of a united Europe as an element of peace and progress in the world. 